\title{
Teknolojik Yenilikler Doğrultusunda Mimarlık Eğitim Mekanlarının Dönüşümü: Yurtdışındaki ve Türkiye'deki Mimarlık Okulları Üzerine Bir Araştırma
}

\author{
Dilara RZAZADE YILMAZ ${ }^{1 *}$, Sibel POLAT ${ }^{2}$
}

\begin{abstract}
Öz
$\mathrm{Bu}$ çalışmanın amacı, uluslararası örnekler üzerinden mimarlık eğitiminde kullanılan teknolojik yenilikleri ve bu bağlamda intiyaç duyulan mekânsal gereksinimleri ortaya koyarak, Türkiye'deki mimarlık eğitim mekânlarının tasarımına/dönüştürülmesine yönelik öneriler geliştirmektir. Çalışmanın literatür araştırmasıyla geliştirilen kuramsal kısmında, teknolojinin yükseköğretimdeki rolü ve mimarlık eğitimindeki yeri tartışılmıştır. Alan çalışması kısmında ise, yurtdışındaki teknoloji odaklı yedi mimarlık okulunun eğitim programlarında kullanılan teknolojik yenilikler, buna bağlı mekânsal gereksinimler, standartlar ve tasarım yaklaşımları web sitelerindeki yazılı ve görsel bilgiler ve okulların mimari projeleri üzerinden incelenmiştir. Ayrıca Türkiye'den yedi şehirdeki onaltı üniversitenin Mimarlık Bölümlerinde görev yapan ve sayısal tasarım alanında çalışmaları olan yirmi yedi öğretim elemanı ile teknolojik yenilikler açısından mimarlık eğitim mekânlarının mevcut durumunu ve bu bağlamdaki mekânsal beklentileri tespit etmek için derinlemesine görüşmeler yapılmıştır. Çalışmanın sonucunda, mimarlık eğitiminde bilgisayar destekli tasarımın ve üretimin birlikte gerçekleştirilebileceği, kat yüksekliği ve mekânsal boyutlar açısından esnek, büyüyebilen, dönüşebilen mekânlara ihtiyaç duyulduğu, bunun bilgi paylaşımını, birebir ve işbirlikçi çalışmayı, tasarım ve sunum tekniklerini kolaylaştırdığı görülmüştür.
\end{abstract}

Anahtar kelimeler: Teknolojik Yenilikler, Teknoloji Odaklı Mimarlık Okulları, Mimarlık Eğitim Mekânları, Mekânsal Gereksinimler, Yenilikçi Tasarım Yaklaşımları.

\section{Transformation of Architectural Education Spaces Through Technological Innovations: A Research on Architectural Schools in Turkey and Abroad}

\begin{abstract}
\footnotetext{
${ }^{1}$ Bursa Uludağ Üniversitesi, Fen Bilimleri Enstitüsü, Mimarlık Anabilim Dalı

2 Bursa Uludağ Üniversitesi, Mimarlık Fakültesi, Mimarlık Bölümü

Illgili yazar/Corresponding author: dilararzazade@gmail.com

Gönderim Tarihi: 01.06.2020

Kabul Tarihi: 10.12.2020
}

The purpose of this study is to find out the technological innovations, spatial requirements and contemporary design approaches needed in the technology-oriented architectural education through international examples and to develop recommendations about how the spaces for architectural education should be transformed/designed in relation to the technological innovations in Turkey. In the theoretical part of the study developed by literature research, the role of technology in higher education and its place in architectural education are discussed.

In the case study part, technological innovations and related spatial requirements, standards and contemporary design approaches in seven international architecture schools in which the use of technology form an important part of learning experience were analysed through their architectural projects and information on their websites.In addition, the use of technological innovations in the architectural education of sixteen 
universities in seven cities of Turkey were researched. In order to analyse the current education spaces and the spatial expectations, in-depth interviews were held with twenty-seven academicians working in the architectural departments of these universities. As a result of the study, it was seen that spaces for architectural education should be flexible in terms of widths, lengths and heights of storey to realize CAD/CAM facilities together and to facilitate information sharing, one-on-one and collaborative work, and to develop design and presentation techniques.

Keywords: Technological Innovations, Technology Oriented Architecture Schools, Architectural Education Spaces, Spatial Requirements, Innovative Design Approaches.

\section{GíRiş}

Teknolojinin hızlı değişimi mesleklerin kendisini dönüştürdüğü gibi, yükseköğretimdeki meslek eğitim-öğretimini ve bu eğitimlerin gerçekleştiği mekânları da dönüştürmektedir. Bu kaçınılmaz gerçek, artık meslek eğitiminde öğrenci merkezli yüksek öğretim yaklaşımlarını gündeme getirmektedir. Öğrenci merkezli ekosistemdeki hayatboyu ve çok yönlü öğrenme, yalnızca eğitim ortamında değil, toplum içinde, evlerde, iş yerlerinde ve diğer ortamlarda mobil ve portatif olarak sağlanan çeşitli organizasyonlarda gerçekleşmelidir. Bu yaklaşımın temeli teknoloji odaklı öğrenmeye, öğretmeye ve değerlendirmeye dayanmaktadır. Bu kapsamda teknolojinin formel ve informel öğrenme ortamlarında öğrenmeyi geliştirebileceği, öğrencilerin zamanın ve mekânın geleneksel engelleri dışında öğrenme fırsatlarına, coğrafi konuma ve kaynağa bakılmaksızın yüksek kaliteli öğrenme kaynaklarına erişmelerine, disiplinlerarası eğitim modelleri aracılığıyla gelişmiş öğrenme biçimlerini deneyimlemelerine, engelli öğrencilerin eğitim programlarına ve etkinliklere katılmalarına ve bunlardan faydalanmalarına imkan vereceği belirtilmiştir (South, 2017, s. 84). İçinde bulunulan Covid 19 pandemisi de eğitim-öğretimde teknolojik yeniliklerin kullanımının ne kadar önemli olduğununu göstermektedir.

Türkiye'de yükseköğretimde teknolojinin kullanımı meselesi gerek yükseköğretimin genişlemesi politikası, gerekse son zamanlarda yaşanan Covid 19 pandemisi nedeniyle önemli bir tartışma alanı olarak karşımıza çıkmaktadır. Ülkemizde yükseköğretim son yıllarda hızlı bir büyüme sürecine girmiş, özellikle 2006'dan sonra yükseköğretimle ilgili kanunlara dayanarak hükümetlerin izlediği politikalarla üniversitelerin tüm yurt geneline yayılması amaçlanmıştır. Türk yükseköğretiminin genişlemesinin dayandığı gerekçeler, temel olarak küreselleşme ve uluslararasılaşma doğrultusunda dünyada yaşanan değişimlerle ilişkili olsa da, bunun ulusal bazda sosyolojik, ekonomik, ideolojik ve politik gerekçeleri de bulunmaktadır (Acer ve Güçlü, 2017, s. 28-29). Ancak yükseköğretim veren üniversite sayısının hızlı artışı niceliksel ve niteliksel birtakım sorunları da beraberinde getirmektedir. Özellikle az gelişmiş illerde kurulan üniversitelerin idari ve akademik kadrolarının yetersiz olduğu, hükümet desteğinin üniversitenin fiziksel ve teknolojik altyapı eksikliğini gideremediği, tüm bunların akademik performansı düşürdüğü ve yeni açılan üniversitelerin yerel kurumlar olarak kaldığı ifade edilmektedir (Acer ve Güçlü, 2017, s. 32-33, Şenses, 2007, s. 3, Türk Eğitim-Sen, 2012, s. 19). Yükseköğretimin fiziki imkanlarının çağdaş bir yükseköğretim yaptırabilecek düzeyde olmadığı, öğrenci başına düşen derslik, laboratuvar, sosyal tesis gibi kapalı mekanların dünyadaki çağdaş üniversitelere göre düşük olduğu belirtilmektedir (Mutluer, 2008, s. 8).Bu sorunlar karşısında YÖK Yükseköğretim Sisteminin yeniden yapılandırılması sürecini başlatmıştır.

Son yıllarda teknolojinin Türk yükseköğretimde kullanımıyla ilgili çalışmalar da yapılmaktadır. Bu kapsamda bir devlet üniversitesindeki öğretim üyeleri üzerinde 
yapılan bir araştırmada ülkemizde eğitim-öğretim kurumlarında teknolojinin yeterince yaygın ve etkin kullanılamadığı, bunun en önemli nedeninin teknolojinin bir amaç olarak görülmesi, teknolojiyi eğitim-öğretim sürecinde etkin kılmaya yönelik yatırımların göz ardı edilerek, teknolojik kaynak sağlanmaya yönelinmesi olduğu ifade edilmiştir. Eğitimöğretim sürecinde teknolojinin aktif kullanımı için, teknolojik kaynakların nitelik ve nicelik olarak geliştirilmesi, bu kaynaklara erişimde fırsat eşitliğinin sağlanması, eğitim programlarına teknolojinin entegre edilmesi, teknolojiyi verimli bir şekilde kullanabilmeleri için akademik ve idari personelin geliştirilmesi ve bu konuda teknik destek personelinin sağlanması gerektiği belirtilmiştir (Yiğit, Zayim ve Yıldırım, 2002, s. 49-50). Yine bir devlet üniversitesinde öğrenciler üzerinde yapılan bir araştırmada ise, öğretim teknolojilerinin öğrenciler arasında kullanımının yaygın olduğu, ancak bunların öğretim elemanları tarafından kullanımının az olduğu ortaya çıkmıştır. Teknoloji kullanımındaki eksikliklerin özellikle sınıf ve laboratuvar koşullarının yetersiz olması, donanımsal eksiklikler ve öğretim elemanlarının bu teknolojileri kullanmadaki bilgi eksiklikleri konusunda yoğunlaştığı görülmüştür (Çağıltay ve ark., 2007, s. 214-215)

Teknolojik değişim ve dönüşümleri eğitim mekanlarına yansıtmakta mimarlık disiplinine önemli bir rol düşmektedir. Çünkü mimari tasarım sürecinde kullanıcı gereksinimlerinin karşılanması en temel konudur. Kullanıcı gereksinimleri teknolojinin gelişmesine paralel olarak zaman içinde değişir. Bu gereksinimlerin doğru analiz edilmemesi, fiziksel ve psiko-sosyal konfor koşullarını düşürerek, tasarlanan mekânın verimli bir şekilde kullanımını aksatır ve mekânda verilen eğitim-öğretimin kalitesini düşürür. Yeni geliştirilen teknolojiler doğrultusunda mimarlık eğitim mekanlarının dönüştürülmesi gerektiğini vurgulayan sayılı çalışma bulunmaktadır. Galan (2017, s. 11-12), 21. yüzyılda geleneksel sınıflar yerine yeterli yazılımı, donanımı ve mobilyaları içeren, uygun konfor koşullarına ve mimari forma sahip, esnek ve geniş teknolojik sınıfların geliştirilmesi gerektiğini belirtir. PAB (2016), nitelikli eğitim-öğretim için interaktif ve katılımcı eğitim modellerine uygun, yeni nesil teknolojilerin entegre edildiği nitelikli mekanların önemini vurgulamaktadır. Bu nedenle meslek eğitim-öğretiminin gerçekleştiği yükseköğretim mekânlarının teknolojiyle birlikte nasıl değişmesi gerektiğini, tasarımcı yetiştiren kurumlar olarak mimarlık eğitimi ve mekânları üzerinden değerlendirmenin faydalı olacağı düşünülmektedir.

Değişken ve dinamik bir süreç olan mimarlık eğitimi, stüdyo ağırlıklı, tasarım merkezli, özgün ve özgür bir ortam yaratan, farklı sanat dallarının öğrencinin yaratıcılığına katkıda bulunduğu, kendine özgü yaklaşımları olan bir sistemdir. 1980'lerden itibaren teknolojinin hızla gelişmesi, bilgisayar programlarının artması ve bu programları kullanabilmek için sürekli gelişen yazılım sistemleri mimarlık eğitiminin belkemiğini oluşturan tasarım stüdyosunun (TS) eğitim ortamını yeniden yapılandırmıştır. Bugün pek çok mimarlık okulu bilgisayar destekli öğrenme biçimlerinin etkinliğini ve esnekliğini yüz yüze iletişimin sosyal yönleriyle birleştirmek için tasarım stüdyosunda karma öğrenmeyi (blended learning) uygulamaktadır. (Achten, Koszewski, Martens, 2011, s. 24), (Garrison, Kanuka, 2004, s. 95-105). Karma öğrenme, geleneksel öğretim ve uzaktan eğitimde kullanılan metodolojileri birleştirir, öğrencilerin TS'de nasıl, ne zaman ve nerede öğrenecekleri konusunda seçenekler sunarak, mevcut öğretim ve öğrenme süreçlerinin belirli akademik intiyaçlar (akademik kaynaklar, müfredat ve eğitim hedefleri) için yeniden yapılandırılabilmesini ve düzenlenebilmesini sağlar. Geleneksel yöntemlerin bilgisayar destekli öğrenme biçimleriyle kombinasyonunu, karşılıklı işbirliğini geliştirmeyi, deneyim alışverişini teşvik etmeyi ve mimariyi yorumlamak için yeni yollar keşfetmeyi, diğer öğrenciler (mimariden veya diğer disiplinlerden) ve aktörler (uzmanlar ve diğer profesyoneller) ile doğrudan ya da uzaktan görüş alışverişinde bulunmayı destekler. Böylece TS, öğrencilerin birlikte çalıştığı disiplinlerarası, birbirine 
bağımlı ve kapsayıcı bir öğrenme alanı haline gelir. Dahası, dijital teknolojilerin TS'ye dahil edilmesi, öğrenme kapasitelerini geliştirerek öğrencilerin çalışma metodolojisini değiştirir. Çevrimiçi eğitim platformları, bloglar ve sosyal ağlar, öğrencilerin bilgi alışverişinde bulunmak, her türlü öğrenme içeriğine erişmek, çalışmalarını özgürce yayınlamak ve farklı aktörlerle ortak konuları tartışmak için kullandığı dijital kaynaklardan bazılarıdır (Masdeu, Fuses, 2017, s. 6-23). Temsil araçlarının ve ortamlarının dijitalleştiği bu ortamda stüdyo eğitimi, merkezine farklı disiplinleri ve teknik alanları alarak, bilgiyi katmanlar halinde birlikte inşa ederek, geleneksel eğitim ortamına göre daha entegre ve deneysel süreçler içeren bir ağ ve iletişim ortamına evrilebilir (Özgenel, 2020).

Bugün teknoloji odaklı mimarlık eğitimi giderek önem kazanmaktadır. Dünyadaki en başarılı mimarlık okullarının hangileri olduğu konusunda yapılan araştırmalarda da teknolojik yeniliklerin mimarlık programıyla entegrasyonu bir değerlendirme kriteri olarak karşımıza çıkmaktadır. Bu alandaki araştırma şirketlerinden biri olan Design Intelligence profesyonel mimarlarla anketler yaparak ABD'deki mimarlık okullarını lisans ve yüksek lisans düzeyinde üç farklı başlık altında değerlendirmektedir. Bu çerçevede akredite edilmiş okullar; en fazla takdir edilen mimarlık okulları, işverenler tarafından mezunlarının en fazla tercih edildiği mimarlık okulları ve mimarlık programlarının 12 farklı odak alanındaki başarısına göre mimarlık okulları şeklinde her sene derecelendirilmektedir. 12 odak alanı içerisinde tasarım teknolojilerinin kullanımı da yer almaktadır. Bu alanda yüksek lisans düzeyinde başarılı olan okulların diğer iki kategoride de ilk yirmi içinde yer aldığı görülmektedir (Url - 1). QS World University Rankings'in 2020 sıralamasına göre ise, teknoloji üniversitesi veya enstitüsü çatısı altında yer alan mimarlık okullarının ilk beş içerisinde yer aldığı görülmektedir (Url - 2). Kısaca, teknoloji odaklı mimarlık okullarının mimarlık eğitim-öğretimi açısından en başarılı okullar olarak dünyada öne çıktığı, öğrenciler tarafından tercih edildiği ve mimarlık eğitimine ve mesleğine yön verdiği söylenebilir.

Diğer yandan Türkiye'deki mimarlık eğitiminde gerek yükseköğretimin genişleme politikasından, gerekse teknolojik yeniliklerin mimarlık eğitimine adapte edilememesinden kaynaklanan bazı sorunlar göze çarpmaktadır. Dokuzuncu Mimarlık ve Eğitim Kurultayında gerçekleşen forumlarda öğrenciler; akademisyenler arasındaki koordinasyon eksikliği nedeniyle eğitim programlarında ders çakışmaları olduğunu ve istedikleri dersleri alamadıklarını, akademisyenlerin sayısal olarak az, sınıfların kalabalık olduğunu, bu yüzden projeleriyle ilgili görüşmek için yeterli süre alamadıklarını, stüdyo şartlarının yetersiz olduğunu, her öğrenciye bir masa düşmediğini, kalabalıktan dolayı arkadaşlarının projelerini görüp, fikir paylaşımı yapamadıklarını, stüdyoların 7/24 kullanıma açık olmadığını, öğrencilere farklı çalışma alanlarının sunulmadığını, teknolojik yeniliklere rağmen eğitimde geleneksel yöntemlerde ısrar edildiğini belirtmişlerdir (TMMOB, 2018, s. 119). Ankara akademisyen forumu sonuçlarında, eğitim ortamının önde gelen sorunları, okul sayısının artışı ve bu okullarda fiziksel (mekansal ve altyapı) koşulların özellikle stüdyo mekanlarının sahip olması gereken özelliklerinin ve insan kaynakları standardının (öğretim elemanı ve öğrenci sayısı) sağlanamaması olarak tanımlanmıştır. İstanbul akademisyen forumu sonuçlarında, gelişen teknolojiyle birlikte dünyada yaygınlaşan uzaktan eğitimin giderek yayılacağına vurgu yapılmış, mekandan bağımsız olan bu uygulamaların eğitimde farklı yöntemler gerektireceği ifade edilmiştir (TMMOB, 2018, s. 138-140). Kamunun nitelikli yapılı çevrelerde yaşayabilmesi için benimsenecek temel ilkeleri vurgulamak ve bu ilkeler paralelinde paydaşlarla birlikte verimli çalışmalar üretebilmek amacıyla geliştirilen Türkiye Mimarlık Eğitim Politikasında ise, yetkin bir eğitim kadrosuyla birlikte eğitim kalitesini destekleyecek fiziki ve niceliksel verilerin karşılanmasının eğitim kurumlarının önceliği olması gerektiği, teknolojik, dijital 
gelişmeler ile geleneksel eğitim-öğretim yöntemleri arasında entegrasyon kurulması gerektiği belirtilmiştir (TMMOB, 2020, s. 4,5,8).

$\mathrm{Bu}$ doğrultuda uluslararası ölçekte teknoloji odaklı mimarlık eğitimi veren okulların kullandığı teknolojik yeniliklerin ve bunların gerektirdiği yeni eğitim mekânlarının incelenmesinin Türkiye'deki mimarlık eğitiminin ve mekanlarının teknolojik yeniliklerle bütünleştirilmesi açısından faydalı olacağı düşünülmektedir. Çalışma kapsamında dünyanın en başarılı mimarlık okulları listesinden seçilen okullar, mimari projeleri, web sitelerinde yer alan eğitim planları ve mekansal altyapı verileri ve fotoğrafları üzerinden incelenmiştir. Ayrıca Türkiye'de teknolojik yeniliklerin kullanımı açısından üniversitelerin mimarlık fakültelerinin mekansal altyapılarının ve burada çalışan akademisyenlerin beklentilerinin sorgulanması da gerekmektedir. Çalışma kapsamında Türkiye'deki farklı devlet ve vakıf üniversitelerinden, özellikle sayısal tasarım alanında çalışmaları olan akademisyenlerle derinlemesine görüşmeler yapılmıştır. Çalışmada test edilecek hipotezler şunlardır:

1. Teknolojik yenilikler mimarlık eğitim mekânlarının niceliksel ve niteliksel özelliklerini değiştirir.

2. Gelişmiş ülkelerde teknolojik yenilikler mimarlık eğitim mekânlarının tasarımında/dönüştürülmesinde etkin bir rol oynamaktadır.

3. Türkiye'deki mimarlık eğitim mekânları teknolojik yeniliklere uyumlu değildir.

Bu kapsamda çalışma, teknoloji, eğitim ve mimarlık arasında ilişki kurarken, nitelikli eğitim için mekân kalitesinin gerekliliğini vurgulamakta, Türkiye'deki mimarlık eğitiminin gelişmesi ve bu konudaki öncü okullarla rekabet gücünün arttırılması için çağın gereksinimlerini karşılayacak ve teknolojik yeniliklere adapte olabilecek eğitim mekanları için yenilikçi tasarım yaklaşımları ve mekânsal öneriler sunmaktadır (Rzazade, 2018, s. 4).

\section{MATERYAL VE YÖNTEM}

Çalışmanın giriş kısmı literatür araştırmasına dayanmaktadır. Ayrıca bir alan çalışması yapılmıştır. Alan çalışmasının amacı, değişen ve gelişen teknoloji bağlamında Türkiye'deki mimarlık eğitim mekânlarının mevcut durumunu uluslararası örneklerle karşılaştırmak ve akademisyenlerin teknolojik yeniliklerle ilişkili mekânsal beklentilerini tespit etmek olarak belirlenmiştir.Alan çalışması iki kısımdan oluşmaktadır. Birinci kısımda dünyanın en başarılı mimarlık okullarının kullandığı teknolojik yeniliklerin ve bunların gerektirdiği yeni eğitim mekânlarının incelenmesi hedeflenmiştir. Bu kapsamda araştırma şirketlerinin belirlediği en başarılı mimarlık okulları listelerinden seçilen 7 okul, mimari projeleri, web sitelerinde yer alan eğitim planları ve mekansal altyapı verileri ve fotoğrafları üzerinden incelenmiştir. Ayrıca yurtdışındaki 15 mimarlık okulunda görev yapan ve sayısal tasarım alanında çalışmaları olan 98 öğretim elemanına ve bu okulları tasarlayan tasarım ofislerine ve mimarlarına e-mail yoluyla teknolojik yeniliklerin kullanımı ve bunların mimari projelerine nasıl yansıdığı konusunda görüşme soruları gönderilmiş, sadece 4 öğretim elemanından ve bir tasarım ofisinde çalışan mimardan geri dönüş alınmıştır. Çalışma kapsamında Amerika'dan Georgia Tech Mimarlık Okulu (Fot. 26) ve Massachusetts Teknoloji Enstitüsü (MIT) Mimarlık Fakültesi (Fot. 31), Kanada'dan Waterloo Mimarlık Okulu (Fot. 27), İsveç'ten Royal Teknoloji Enstitüsü Mimarlık Okulu (Fot. 28), Singapur'dan Singapur Teknoloji ve Tasarım Üniversitesi Mimarlık ve Sürdürülebilir Tasarım Fakültesi (Fot. 29), Hollanda'dan Delft Teknoloji Üniversitesi Mimarlık Fakültesi (Fot. 30) İsviçre'den ETH Zürih Mimarlık Fakültesi (Fot. 32) hem mimarlık programlarında kullandıkları teknolojik yenilikler, hem de bu yeniliklerin sunulduğu 
mekanlar açısından analiz edilmiştir. Seçilen okullar, mimari projeleri, web sitelerinde yer alan eğitim planları ve mekansal altyapı verileri ile teknolojik yeniliklerin kullanıldığı mekanların fotoğrafları üzerinden incelenmiştir.

Alan çalışmasının ikinci kısmı, Türkiye'de teknolojik yeniliklerin kullanımı açısından üniversitelerin mimarlık fakültelerinin mekansal altyapılarının ve burada çalışan akademisyenlerin beklentilerinin ortaya konmasını hedeflemektedir. Bu kapsamda öncelikle Türkiye'de "Mimarlıkta Sayısal Tasarım Sempozyumu"na katılan öğretim elemanlarına ve bu alanda çalışmaları olan (teknolojiyi eğitimde aktif olarak kullanabilen) diğer öğretim elemanlarına e-mail üzerinden ulaşılmaya çalışılmıştır. Çalışma kapsamında Türkiye'deki büyük şehirlerde yer alan köklü devlet üniversiteleri ile maddi olanakları daha geniş olan vakıf üniversitelerinin mimarlık fakültelerinde görev yapan 60 öğretim elemanına derinlemesine görüşme talebi için e-mail gönderilmiş, 7 kentten 16 devlet ve vakıf üniversitesinin mimarlık fakültelerinde görev yapan 27 öğretim elemanı ile 2018 yılında derinlemesine görüşmeler yapılmıştır.

Görüşme için ziyaret edilen üniversiteler ODTÜ (Orta Doğu Teknik Üniversitesi) (Fot. 33), ITÜ (İstanbul Teknik Üniversitesi) (Fot. 34), YTÜ (Yıldız Teknik Üniversitesi), KOÜ (Kocaeli Üniversitesi), GTÜ (Gebze Teknik Üniversitesi), ANAÜ (Anadolu Üniversitesi), IYYTE (İzmir Yüksek Teknoloji Üniversitesi), DEÜ (Dokuz Eylül Üniversitesi), YÜ (Yaşar Üniversitesi), TEDÜ (TED Üniversitesi), İDBÜ (İhsan Doğramacı Bilkent Üniversitesi), GÜ (Gazi Üniversitesi), AGÜ (Abdullah Gül Üniversitesi), ERÜ (Erciyes Üniversitesi), IBÜN (İstanbul Bilgi Üniversitesi) (Fot. 35.36), BUÜ'dür (Bursa Uludağ Üniversitesi).

Derinlemesine görüşmeler "teknolojinin mimarlık eğitim mekânlarının tasarımına etkisini" araştırmayı hedeflemektedir. Yarı yapılandırımış görüşme formları iki kısımdan oluşmaktadır:

- Birinci kısım, görüşme yapılan kişilerin bilgilerini kapsamaktadır: Cinsiyet, yaş, akademik unvan, çalıştığı kurum, üniversitede çalıştığı süre, çalışma alanları, lisans düzeyinde verdiği dersler, yüksek lisans düzeyinde verdiği dersler, doktora düzeyinde verdiği dersler.

- 9 sorudan oluşan ikinci kısım, Türkiye'deki mimarlık eğitimi ve mekânlarını teknolojik yeniliklerin kullanımı açısından değerlendirmekte ve uluslararası örneklerle karşıllaştırmalar talep etmektedir (Rzazade, 2018, s. 3-4).

Yüzyüze görüşmeler yaklaşık 15-40 dakika kadar sürmüş, kayıt altına alınmış ve betimsel analizle çözümlenmiştir. Ayrıca ziyaret edilen mimarlık okullarındaki maket stüdyolarında ve dijital üretim laboratuvarlarında ders saati içerisinde veya ders saati dışında fotoğraf çekimleri yapılmış ve laboratuvarlardaki görevli elemanlardan mekânın kullanımına yönelik bilgiler alınmıştır.

\section{BULGULAR}

\subsection{YURTDIŞINDA MIMARLIK OKULLARINDA KULLANILAN TEKNOLOJIK YENILIKLER}

Gelişmiş ülkelerdeki mimarlık okulları, teknolojik yenilikleri farklı etkileşim sistemleri ve kullanım olanakları ile birleştirerek eğitimde yeni stratejiler ve yöntemler geliştirmekte ve bunları eğitim mekanlarıyla bütünleştirmektedir. Çizelge 1'de mimarlık eğitiminde kullanılan teknolojik yenilikler kısaca özetlenmiştir: 
Yapılan araştırmaya göre yurtdışından seçilen bütün mimarlık okullarında teknolojik yeniliklerden; uzaktan/çevrimiçi eğitim, çevrimiçi konferans, BDT ve BDÜ, dijital sunum, simülasyon; SG ve AG, STS ve sanal jüri, RK olanaklarının kullanıldığı görülmüştür. Bu olanaklar doğrultusunda mimarlık eğitim programının içeriğinin değiştiği, Programlamaya Giriş, Mimari Modelleme ve Dijital Medya, Simülasyon, BBM, Parametrik Tasarım, 3B Modelleme ve Animasyon, Robotik Üretim, Dijital Tasarım ve Üretim, Sunum ve Sergileme gibi derslerin programa entegre edildiği tespit edilmiştir.

Teknolojik yenilikler arasında sadece bilgisayar destekli üretim ve RK (Robotik Kol) için dijital üretim laboratuvarlarına gereksinim duyulduğu, diğerlerinin mekandan bağımsız olarak gerçekleştirilebildiği görülmüştür. Bu okullarda tasarım ve üretimin birlikte gerçekleştirildiği fablab+stüdyolar, hangar tipli geniş ve yüksek stüdyolar, bilgisayarla bireysel çalışma kabinleri, çok amaçlı sirkülasyon alanları, açık jüri alanları, 24 saat açık çalışma alanları, işbirlikçi çalışma mekânları, açıklık hissini artıran mekânlar, total mekânlar, harekete teşvik eden mekânlar, değişen gereksinimlere cevap verebilecek farkı düzenlemelere uyum sağlayabilen mekânların öne çıktığı tespit edilmiştir. Böylece teknolojik yeniliklerin mimarlık eğitim mekânlarının niceliksel ve niteliksel özelliklerini değiştirdiği görülmüştür (1. Hipotez).

Çizelge 1: Mimarlık Eğitiminde Kullanılan Teknolojik Yeniliklere Dair Tanımlar ve Görseller

\begin{tabular}{|c|c|c|}
\hline $\begin{array}{l}\text { Teknolojik } \\
\text { yenilikler }\end{array}$ & Tanımı & Fotoğraflar \\
\hline $\begin{array}{l}\text { Uzaktanl } \\
\text { çevrimiçi } \\
\text { eğitim ve } \\
\text { konferans }\end{array}$ & $\begin{array}{l}\text { Konferansların veya teorik derslerin } \\
\text { önceden kayıt edilerek sistem üzerinden } \\
\text { indirilmesi hem video olarak } \\
\text { izlenebilmesi, hem de yazılı olarak } \\
\text { okunabilmesidir (Rzazade, 2018, s. } \\
13 \text { )(Fot.16) }\end{array}$ & $\begin{array}{l}\text { Oosign Elamonis that } \\
\text { Fot.16: Frank Gehry'nin çevrimiçi yüksek } \\
\text { lisans dersleri (URL - 3) }\end{array}$ \\
\hline $\begin{array}{l}\text { Bilgisayar } \\
\text { Destekli } \\
\text { Tasarım } \\
\text { (BDT) }\end{array}$ & $\begin{array}{l}\text { Çeşitli dijital tasarım programlarıyla } \\
\text { mimari çizimlerin kalem veya fare } \\
\text { kullanılarak 2B (iki boyutlu) veya 3B (üç } \\
\text { boyutlu) ortamda yapılmasına olanak } \\
\text { sağlayan elektronik çizim sistemidir (Wall, } \\
\text { Clegg, Kemp, 1987, s. 464) (Fot.17). }\end{array}$ & tasarlanmış bir mekan (URL - 4) \\
\hline $\begin{array}{l}\text { Bilgisayar } \\
\text { Destekli } \\
\text { Üretim (BDÜ) }\end{array}$ & $\begin{array}{l}\text { Dosyadan fabrikaya olarak adlandırılan } \\
\text { bu döngüde tasarlanan her ürünün BSD } \\
\text { (bilgisayarlı sayısal denetim) } \\
\text { makineleriyle doğrudan üretime } \\
\text { gönderilebilmesidir (Kolarevic, 2003, s. } \\
\text { 314) (Fot.18) }\end{array}$ & $\begin{array}{l}\text { Fot.18: Dijital modelden uygulamaya, } \\
\text { tasarım üretim süreci (Akipek, İnceoğlu, } \\
\text { 2007, s. 247) }\end{array}$ \\
\hline $\begin{array}{l}\text { Dijital sunum } \\
\text { ve sergileme }\end{array}$ & $\begin{array}{l}\text { Dijital tasarım programlarıyla hazırlanan } \\
\text { projelerin dijital sunum platformları } \\
\text { üzerinden, 3B görüntüler ve videolarla, } \\
\text { çıktı alınmadan sunulmasıdır (Fot. 19, } \\
\text { 20) }\end{array}$ & $\begin{array}{l}\text { Fot. 19: Cl3ver programı ile etkileşimli 3B } \\
\text { sunumlar için platform (URL }-5 \text { ) }\end{array}$ \\
\hline
\end{tabular}




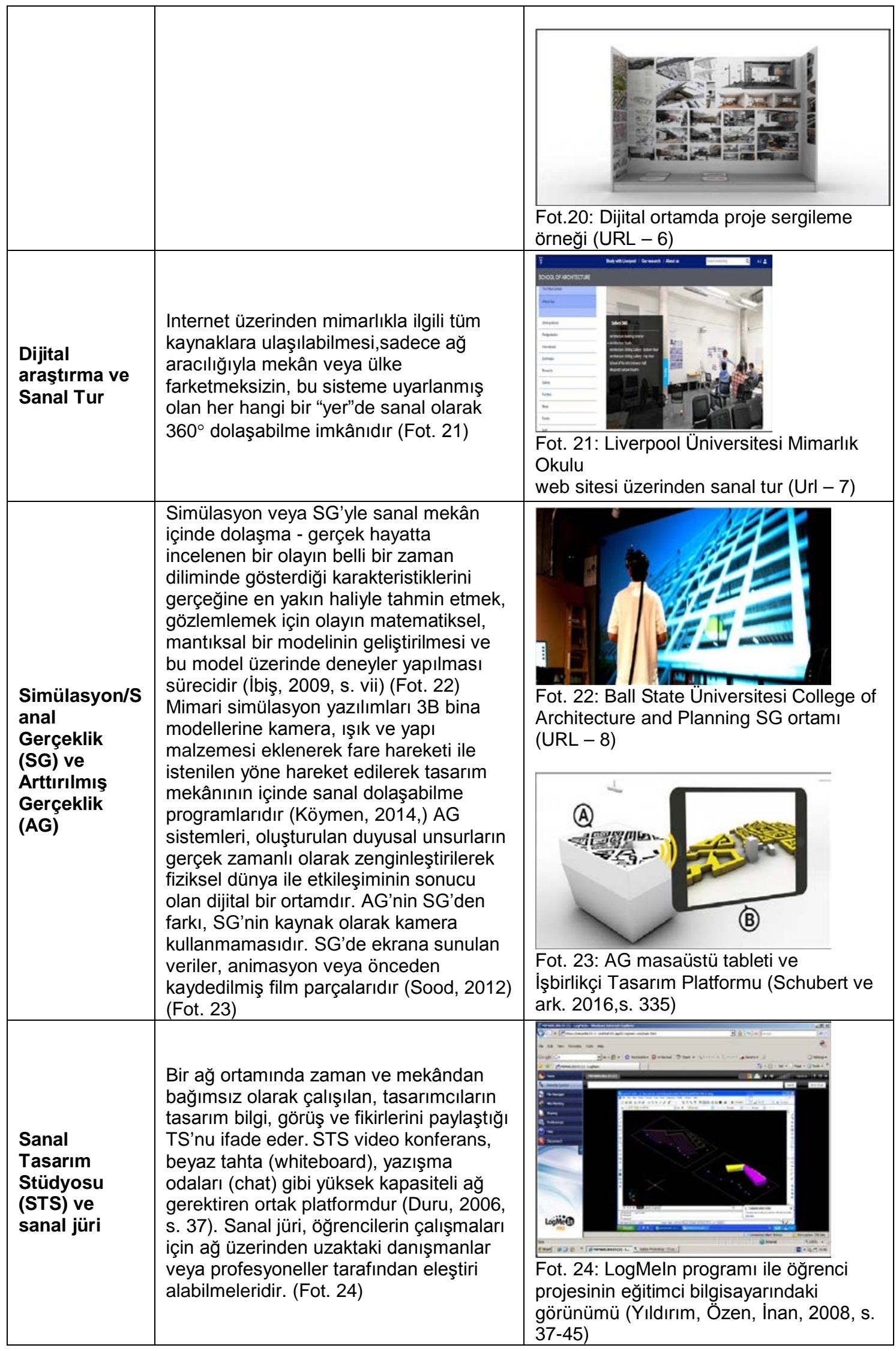




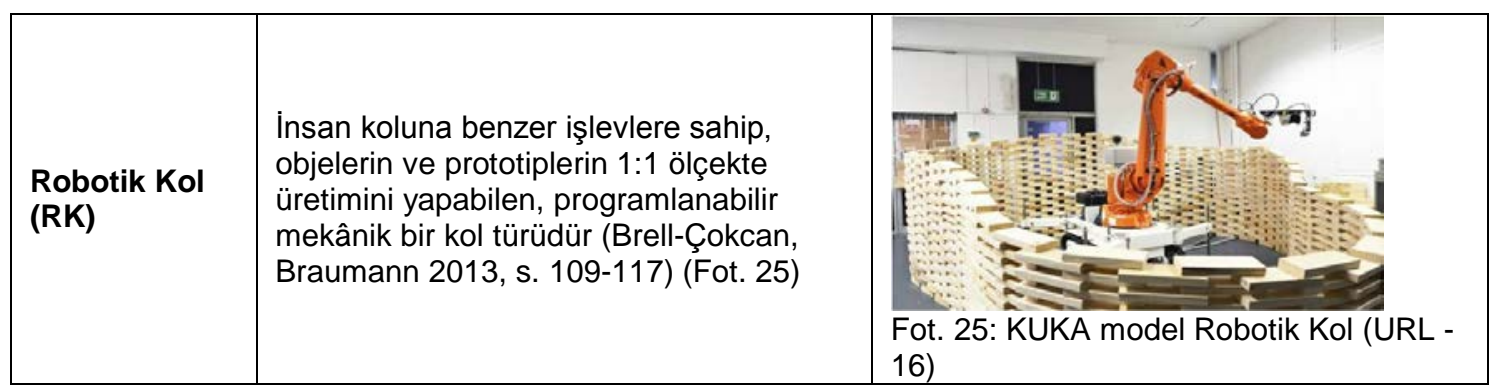

Mimarlık eğitim mekanlarının tasarımına yön veren temel yaklaşımlarda; esneklik (değişebilirlik, dönüşebilirlik), dinamizm, bağlantılılık, akışkanlık gibi fiziksel kavramların, disiplinlerarasılık ve işbirlikçilik, inovasyon ve yaratıcılık, sürekli etkileşim, sosyallik gibi soyut kavramların öne çıktığı belirlenmiştir. Böylece gelişmiş ülkelerde teknolojik yeniliklerin mimarlık eğitim mekânlarının tasarımında/dönüştürülmesinde etkin bir rol oynadığı, yenilikçi tasarım yaklaşımlarını tetiklediği görülmüştür (2. Hipotez).

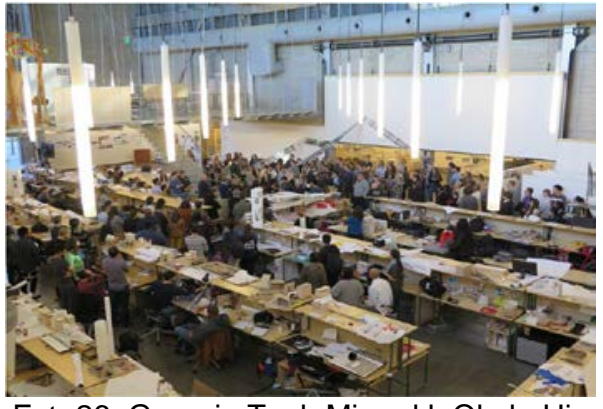

Fot. 26: Georgia Tech Mimarlık Okulu Hinman Araştırma Binası (URL - 9)

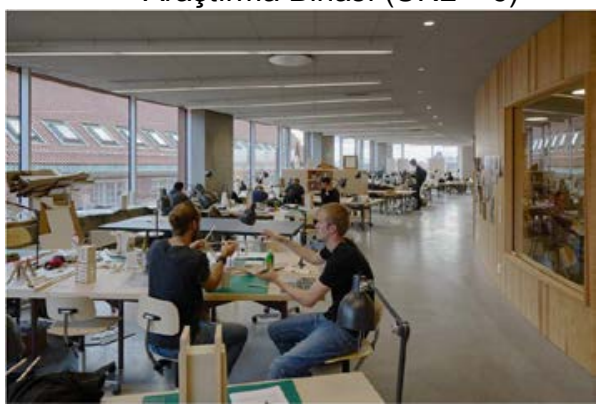

Fot. 28: Royal Teknoloji Enstitüsü Mimarlık Okulu stüdyolar (URL - 11)

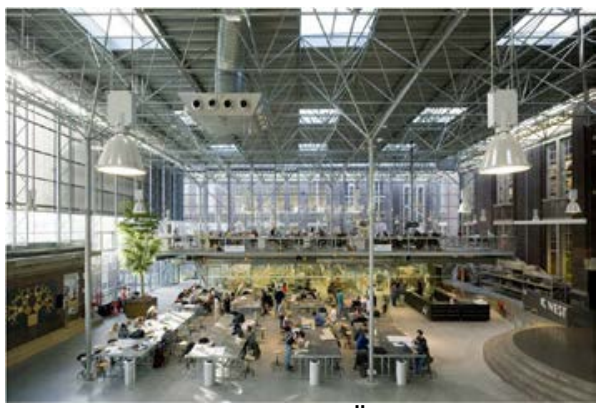

Fot. 30: Delft Teknoloji Üniversitesi Mimarlık Fakültesi Model Stüdyosu (URL - 13)

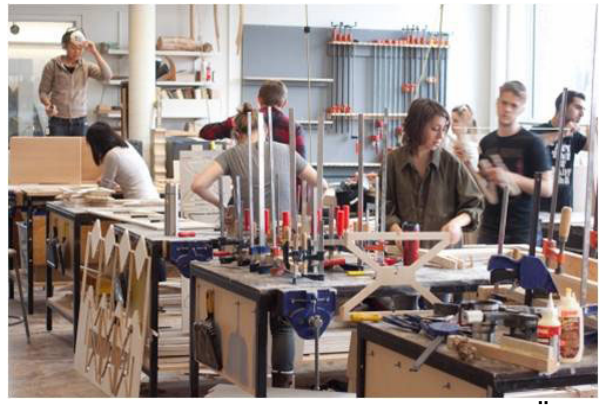

Fot. 27: Waterloo Mimarlık Okulu Dijital Üretim Laboratuvarı (URL - 10)

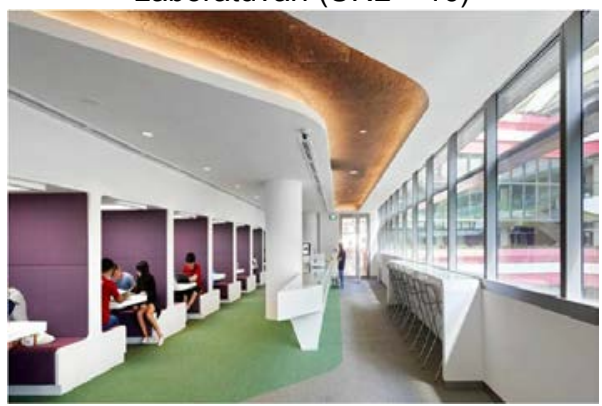

Fot. 29: Singapur Teknoloji ve Tasarım Üniversitesi kapsül çalışma alanları (URL - 12)

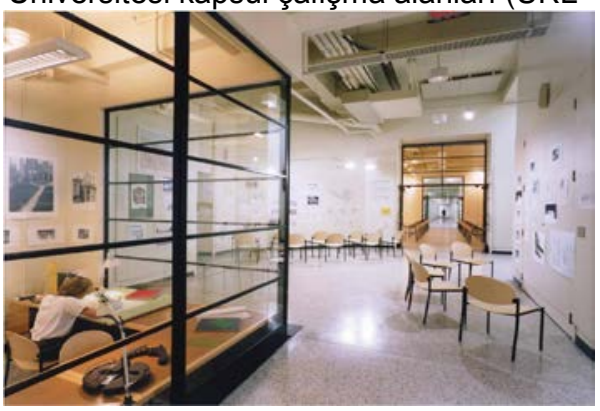

Fot. 31: MIT Mimarlık Fakültesi esnek jüri alanları (URL - 14) 


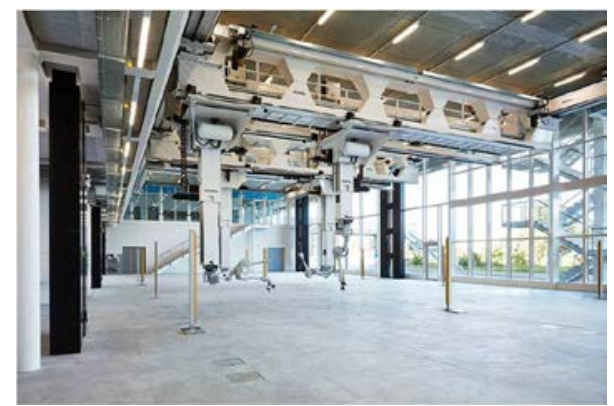

Fot. 32: ETH Zürih Mimarlık Fakültesi

"Arch_Tec_Lab" (URL - 15)

\subsection{TÜRKIYE'DEKI MIMARLIK EĞITIM MEKANLARININ TEKNOLOJIK YENILIKLERLE ÍLIŞKISI}

\section{- Ülkemizdeki mimarlık eğitim-öğretiminde kullanılan teknolojik yenilikler ve bunların meslek eğitimine ve meslek pratiğine etkisi}

Yapılan görüşmeler sonucunda, teknolojik yeniliklerin çoğunlukla yüksek lisans düzeyindeki derslerde kullanıldığı, lisans düzeyinde ise, çok az üniversitenin, daha çok özel üniversitelerin bunlardan faydalandığı ortaya çıkmıştır. Lisans düzeyinde; Lazer Kesici, 3B Yazıcı, Tarayıcı, BSD, Vacuum Forming gibi makinelerin kullanıldığı/ Prototiping Fabrication, Geometric Modelling, BBM, BDT, BDÜ, BDMT (Bilgisayar Destekli Mimari Tasarım) gibi derslerin yapıldığı/ ARDUINO, Rhino, Revit programlarının, yüksek lisans düzeyinde; SG, AG, SGG, RK olanaklarının kullanıldığı belirtilmiştir. Teknolojinin genel olarak öğretim elemanlarının çabalarıyla kendi derslerine entegre edildiği, teknolojiyi müfredata entegre edebilen okulların sınırlı olduğu ifade edilmiştir. Lisans düzeyinde teknolojik yenilikleri öğrencilerin proje geliştirme aşamasında değil de, final ürünlerinde sonuca ulaşmak için kullandıkları; bunun yanısıra, hâlâ geleneksel yöntemlerle eğitim veren okulların olduğu ifade edilmiştir (Rzazade, 2018, s. 95). Görüşmelerden öne çıkan bazı örnekler aşağıda yer almaktadır:

Görüşme 22. ERÜ Mimarlık Fakültesi Dr. Öğr. Üyesi

... "Son dönemde mimarlık okullarının sayısı arttı. Dolayısıyla bu teknolojiyle ilgili çağa adapte olan okul sayısı çok az. Benim bildiğim bir ya da iki tane. 3B yazıcı, lazer kesim cihazı olan, parametrik tasarımla ilgili lisans düzeyinde çalışmalar yapan yok. Hepsi yüksek lisans ve doktora düzeyinde. Dolayısıyla mimarlık eğitimini ve mesleğini çok değiştirmedi şu anda ya da etkilerini Türkiye'de göremedik biz. Belki 510 sene sonra göreceğiz. Yurdışındaki eğitimi biraz takip ettiğim için söylüyorum. Bizdeki eğitim-öğretim kalitesi de çok düşük. Öğrenci sayısıyla ve mimarlık fakültesiyle alâkalı." (Rzazade, 2018, s. 228).

\section{Görüşme 26: YTÜ Mimarlık Fakültesi Doç.Dr.}

... "Öğrenciliğimden başlayarak teknolojilerle dördüncü yılımda tanıştım. ODTÜ'de eğitim gördüm. Orası bu işin çok önde gittiği yerlerden biri. Çünkü bir okulda ne kadar dışarıya açık olanaklar sağlanırsa, yurtdışına gidip gelme gibi, teknolojinin Türkiye'de daha hızlı özümsenmesini sağlarsınız, o kadar hızlı gelişir o okul. O bakımdan benim okulum vizyoner, önü açık bir okuldu. Bir de böyle bir sistemi getirirken kafanın açık olması gerekiyor. Geleneksel bakış açısı da olabiliyor çünkü teknolojik altyapının daha sınırlı olması gerektiğine inanan...Dördüncü sınıftayken ben dijital tasarım stüdyosu kurulmuştu. Ben de orada eğitime başladım. Son yıllarda da Türkiye'de tüm okulların müfredatında kesin birinci veya ikinci sınıftan "Bilgisayar Teknolojilerine Giriş" diye bir ders var. Autocad, 2B,3B çizim programları, 3Ds Max gibi altyapı öğretiliyor. Bunun dışında bir de seçmeli dersleri çoğu okulda görüyorum, ama bazı okullarda daha az, daha üretime yönelik, 3B çıktı almaya yönelik Rhino gibi başka araçlar da öğretilebiliyor. Bu araçlardan sonra öğrencinin çıktı alması, o arayüzü tanıması da bekleniyor. Bu teknolojik yenilikler bizim için şu anda en şey nokta, her insanın bilgisayar teknolojisi dili lisansta bu düzeyde kalıyor, daha da ileriye gitmiyor. Son 20 yılda bilgisayara inanılmaz bir şekilde geçiş oldu. Paradigma hızlı gelişti. İlk başta Autocad'e başlayan bürolarda şimdi onun yerini Revit, BBM almaya başladı. Yani 2B çizimler değil de, aslında aynı anda binanın duvar boyutunu, hangi malzemeden yapıldığı gibi bütün bilgileri içeren bir sistem. Hem 3B çıktılar veriyor, hem 
de kesit ve plan gibi. Her türlü farklı görselleştirme veren sistemler. Bu sistem tabii mimarlık mesleğini ele geçirmeye başlayınca, bürolar tamamen bu şekilde ilerlemeye başlayınca, ister- stemez eğitime de onun yansıması gerekiyor. O yüzden BBM programları lisans düzeyinde derslere entegre edilmeli. Henüz bizim okulumuzda mesela yok." (Rzazade, 2018, s. 253-254).

Kısaca, mimarlık eğitimine teknolojinin adaptasyonundan önce eğitimde yükseköğretimin genişleme politikasından kaynaklı pek çok sorunun yaşandığı, teknolojik yeniliklerin mimarlık eğitimini çok etkilemediği, çünkü mimarlık eğitiminin teknolojiyi içselleştiremediği, bunların daha çok kısmen eğitime adapte edildiği, geleneksel bakış açısının hala eğitimde yerini koruduğu söylenebilir. Buna rağmen işhayatındaki rekabetten dolayı meslek pratiğinin daha hızlı bir şekilde teknolojik yeniliklere adapte olduğu görülmektedir.

\title{
- Ülkemizdeki mimarlık eğitim-öğretiminde teknolojik yeniliklerin kullanımının yeterliliği ve bu konuda başarılı bulunan ulusal mimarlık okulları
}

Yapılan görüşmeler sonucunda mimarlık eğitiminde teknolojik yeniliklerin kullanımının çoğunlukla yeterli olmadığı, devlet üniversitelerinden ITÜ, ODTÜ, MSGSÜ, özel üniversitelerden İBÜN, MEF Üniversitesi, YÜ'de teknolojik yeniliklerin diğerleri ile kıyaslandığında daha başarıı ve daha iyi kullanıldığı ifade edilmiştir. Teknolojik yeniliklerin kullanımının yeterli olabilmesi için müfredatın devrim niteliğinde değiştirilmesi, üniversitelerin ekonomik açıdan iyileştirilmesi gerektiği, fablab ların kurulması, lisans düzeyinde birinci sınıftan itibaren teknoloji odaklı derslerin verilmesi gerektiği, okullarda önce teknolojik altyapının kurulması gerektiği belirtilmiştir (Rzazade, 2018, s. 95-96). Görüşmelerden öne çıkan bazı örnekler aşağıda yer almaktadır:

\section{Görüşme 21: AGÜ Mimarlık Fakültesi Öğr. Gör.}

... "Türkiye'de yeterli değil. Biz de çok yakın takip etmemize rağmen henüz eğitime entegre edemedik. Özellikle eski nesil tasarım eğitimi ve yeni teknolojik gelişmeleri çakıştırma kısmında yetersiz kalıyor. Öğrenciler bu imkânları yeterince kullanamıyorlar. Çünkü o şekilde yönlendirilmiyorlar. Bizim üniversite en azından şu anda yeterli değil. Takip ettiğim kadarıyla iTÜ'de bazı çalışmalar görüyorum. İÜN bu konularda iyi görünüyor. Yeni açılan MEF Üniversitesi'nde de RKla üretim yaptıklarını, parametrik tasarım ve görselleştirme alanında farklı yaklaşımları olduğunu gördüm." (Rzazade, 2018, s. 224)

\section{Görüşme 6: KOÜ Mimarlık Fakültesi Doç.Dr.}

\begin{abstract}
... "Bu konuda, ITÜ başarılı bence. KOÜ, İzmir, ODTÜ'nün iyi olduğunu biliyorum. Bu bir süreç. Önce bunu öğrenmek lazım, sonra öğretmek, sonra da bizim öğrettiklerimizin uzun vadede yoğun bir şekilde kullanılıyor olması lazım. Bu süreç başladı. O yüzden de iyi gidiyor bence." (Rzazade, 2018, s. 146).
\end{abstract}

\section{Görüşme 23: İBÜN Mimarlık Fakültesi Dr. Öğr. Üyesi}

..."Tanışmak anlamında yeterli, ama öğrencilerin tecrübe edinmeye daha heveslendirilmesi lâzım. Bu yolu da gösterip tercih eden öğrencilerin oradan da geçebilmelerini sağlamak. Hiçbir alet veya ekipman iyi tasarımın doğrulayıcısı değil tabii. Entellektüel derinlik yine öğrencide bitiyor. "Mimarlıkta Sayısal Tasarım Sempozyumu"nun bu yıl on üçüncüsü düzenleniyor. Bu çok önemli bir şey. Çünkü bu alanlar ortaya çıkmaya başladığından beri yurtdışında eğitim gören hocalarımız bu platformu kurdular. Bütün kişiler ulusal anlamda ne yapıldığı ile ilgili son çalışmaları orada görebiliyorlar." (Rzazade, 2018, s. 234). (Fot 3435).

Özetle, köklü devlet ve bazı vakıf üniversitelerindeki mimarlık fakülteleri dışında mimarlık eğitiminde teknolojik yeniliklerin kullanımının henüz yetersiz olduğu, bunun temel nedenlerinin akademisyenlerin geleneksel eğitim modellerine bağlılığı ile teknolojinin kullanımı konusundaki bireysel eksiklikleri yanında, finansal kaynakların kısıtlılığına bağlı olarak mekansal ve teknolojik altyapının geliştirilememesi olarak ifade edilebilir. 


\section{- Ülkemizdeki mimarlık eğitim-öğretiminde teknolojik yeniliklerin kullanımının uluslararası örneklerle karşılaştırılması ve bu konuda başarılı bulunan uluslararası mimarlık okulları}

Mimarlık eğitimine ayrılan bütçenin kısıtlılığı nedeniyle Türkiye'de teknolojik yeniliklerin kullanımının yetersiz kaldığı ifade edilmiştir. Robotik teknolojilerin kullanımında yurtdışı örneklerin daha başarılı oldukları, fablab ların gelişmiş üretim teknolojileri ile donatıldığı, bu alanda öğretim elemanları kadrosunun da geniş olduğu ve ayrılan bütçelerin teknolojik yeniliklerin kullanımına rahatlıkla imkân sağladığı belirtilmiştir. ETH Zürih, MIT, AA Mimarlık Okulu, Delft TÜ, IAAC, SCIARCH, UCL gibi üniversitelerin bu alanda başarılı oldukları ifade edilmiştir (Rzazade, 2018, s. 96). Yapılan görüşmelerden öne çıkan bazı örnekler şöyledir:

\section{Görüşme 13. YÜ Mimarlık Fakültesi Arş. Gör.}

..."Uluslararası örnek olarak evet, kullanılıyor. Bizim Hollanda'daki üniversitelerle geçtiğimiz yıllarda bayağı iliş̧imiz vardı. Sadece bizim ülkemizde mimarlık fakültelerindeki insanlar hâlâ kırk yıl önce kullanılan öğretim sistemini kullanıyorlar. O yüzden de ne yazık ki çok fazla değişim olmuyor. Tek tük, daha çok özel üniversitelerde...Çünkü bunu da reklam olarak kullanıyorlar. Mimarlıkta yeni yöntemlerle öğretiyoruz gibi. Ama devlet okullarında mimarlık alanında teknolojiyi takip etmek milletin çok ilgilendiği bir durum değil ne yazık ki. Uluslararası örnek olarak, Delft TÜ var. Bizim üniversitede eski dekanımız bu sene orada "Mimari ve Teknoloji” üzerine inanılmaz projeler yapıyor. Delft TÜ ile zaten çalıştaylar yapıyoruz. İtalya'da Politecnico Di Milano var. Orada da teknolojik araçların kullanımı stüdyolarla destekleniyor. Biz Türkiye'de bu noktada biraz daha geri kalmış durumdayız ne yazık ki. YÜ'nde bir tık yakalamaya çalışıyoruz, sadece tek sıkıntı öğrencilerin kapasitesi. Çünkü özel üniversite olduğu için maddi açıdan iyi olan öğrenciler oluyor. Bir dönemde 100 öğrenciden biz sadece on, on beşine öğretme peşinde oluyoruz. Diğerleri pek fazla çalışmıyor." (Rzazade, 2018, s. 187).

Görüşme 11. IYTE Mimarlık Fakültesi Öğr. Gör. Dr.

... "Bu alanda en iyi ETH Zürih'dir. Orada genel olarak teknik mühendislik ekolü olduğu için mimarlığa etkisi de diğer bölümlerle kıyaslandığında herhalde daha kapsamlı, bir paradigma dönüşümünü oraya inşa etmişler ve uzun zamandır bu işi yapıyorlar. Mühendisliğin mimarlıkla arakesitini yaratıcı bir şekilde geliştirebilen bir kadrosu var. O anlamda en iyi okul orasıdır. Daha sonra, Delft TÜ'nin mimarlık eğitimi içerisinde bu tür şeylerin iyi gelişmiş olduğunu biliyorum. Giden arkadaşlardan ve gelen hocalardan onu görüyorum. Tabii bir de Amerika'da maddi olanakları el verdiği için en son olanı getirebiliyorlar. Ama oralara daha çok buralardan insanlar gidiyor. ETH'da, Delft'de bir kaç sene kaldıktan sonra tekrar kendi işlerine geri dönüyorlar gibi. Oradaki örneklerle karşılaştırılabilecek seviyede değil tabii ki. Türkiye'de şu anda bilgisayardan başka, ekonomik olarak çok ciddi sorunlar olduğu için üniversitelerde normal eğitimi doğru düzgün verebilecek sistemi çok zor bir araya getiriyorlar. Başka yapısal sorunlar var. Ama bunu yapabilecek insanlar buraya gelebiliyor. Buraya geldikleri zaman bir şey yapamıyorlar. Yapmak istediklerinde yapacak insan ve heves var, ama bunu sağlayacak bir altyapı yok yani. O altyapıyı kurmak çok zor." (Rzazade, 2018, s. 176-177).

Kısaca, gelişmiş ülkelerdeki mimarlık okullarının teknolojik yeniliklerin kullanımında Türkiye'den önde oldukları, ancak bazı köklü devlet üniversiteleri ile vakıf üniversitelerinin kurumsal olarak veya akademisyenler yurtdışındaki bu okullarla birlikte çalışarak teknolojinin kullanımı konusundaki deneyimlerini geliştirdikleri söylenebilir.

\section{- Ziyaret edilen üniversitelerdeki mimarlık eğitim-öğretiminde kullanılan teknolojik yenilikler ve bunların kullanım alanları}

Uzaktan/çevrimiçi eğitim olanaklarının yetersiz olduğu, çevrimiçi eğitimin sağlanamadığı okullarda çevrimiçi değerlendirme arayüzlerinin (ODTÜ CLASS, UKEY) kullanıldığı, resmi olarak ülkemizde çevrimiçi eğitimin sisteme dahil olmadığı, sadece belli zamanlarda başka bir ülkede olan bir öğretim elemanı ile çevrimiçi bağlantı kurularak dersler veya deneysel çalışmalar yapıldığı belirtilmiştir. Çevrimiçi konferansların lisans düzeyindeki derslerde değil de, yüksek lisans düzeyindeki derslerde yapıldığı, gerekli olduğu zaman üniversite dışından uzmanlarla bağlantı kurarak birlikte dersler yapıldığı ifade edilmiştir. Dijital mimari tasarım olanaklarının (2B, 
3B, animasyon, simülasyon vb) genellikle bütün okullarda sıklıkla kullanıldığı belirtilmiştir. Dijital mimari üretim olanaklarının (BDT, BDÜ) lisans veya yüksek lisans düzeyinde kullanıldığı, kurulan fablab'larda 3B yazıcı, lazer kesim, BDT/BDÜ, 3B tarayıcı, RK, BSD makinelerinin kullanıldığı, aynı şekilde birkaç devlet okulunda ekonomik şartlardan veya öğretim elemanlarının yönlendirmesinden dolayı hâlâ geleneksel yöntemlerin kullanıldığı ifade edilmiştir. Dijital proje sunumlarının KOÜ, ODTÜ, AGÜ, ERÜ, BUÜ'de çeşitli programlardan elde edilen görsellerle yapıldığı, çıktı olarak kağıt üzerinde sunumların azaldığı, YTÜ'de projecting mapping gibi programlarla dijital sunum tekniklerinin kullanıldığı belirtilmiştir. Simülasyon; SG ve AG tekniklerinin KOÜ, ITÜ, ODTÜ, YTÜ'de kullanıldığı, ITÜ'de yüksek lisans veya doktora düzeyindeki bazı araştırmaların SGG ile yapıldığı, ODTÜ'de son bir yıl içerisinde hem araştırma projelerinde, hem de dördüncü sınıflarda bazı gruplarda tasarım tekniği olarak kullanıldığı belirtilmiştir. STS ve sanal jüri olanaklarının yüksek lisans ve doktora düzeyinde tez sunumları kapsamında kullanıldığı, genellikle okullarda sınırlı sayıda sanal tasarım stüdyolarının/jürilerinin yapıldığı, sadece tercih eden öğrenci veya öğretim elemanlarının kullanabildiği görülmüştür (Rzazade, 2018, s. 96-102). Yapılan görüşmelerden öne çıkan bir örnek şöyledir:

Görüşme 15. ODTÜ Mimarlık Fakültesi Prof. Dr.

... "Bunu iki türlü görüyorum: biri, hakikaten eğitim verilen ortamın bu teknolojik vasıtaları kullanıp kullanamaması ile ilgili, üretim olanakları, teknoloji tabanlı tasarım olanakları vs., ikincisi, ders ortamının teknolojik vasıtaları kullanarak öğrenciye ve daha geniş kitleye nasıı ulaştığıyla ilgili. Birincisini, ben kendi kurumumdan biliyorum. İdareci olarak çalıştım ve dekanlık süreci boyunca en fazla yatırım yaptığımız alan teknoloji destekli üretim olanaklarının ve mekânlarının iyileştirilmesi ve zenginleştirilmesine ilişkin. Türkiye'de şu anda mimarlık okulları arasında son iki yıl içerisinde yaptığımız iyileştirme projeleriyle en iyi nitelikli üretimhaneye, işliklere sahibiz. Hatta o projeler bu dönem "Arredamento", "21" gibi dergilerde çıkıyor. Dolayısıyla bizim burada analog üretim (geleneksel, ahşap üretimler) BDÜ de kendi kapasitemizde veriliyor. 3B yazıcılar, tezgahlar, lazer kesiciler gibi. Bununla birlikte, BDT ortamının kendisi iyileştirildi. Eğitime katkısı, şöyle; bu süre zarfında yüksek lisans BDT ve tasarım programlarını inşa ettik, uluslararası iyi kurumlarla bunu bir süre model olarak götürdük. Şu anda o iletişim ağının ortaklıkları falan sonlansa da, biz kendi kapasitemizde bu alandaki yatırımımıza devam ediyoruz. Hatta lisans müfredatının içerisine de girdi. İkinci sınıftan başlarayarak BDT süreç ve teknikleri konusunda lisans derslerimiz oldu. Lisansüstü derslerde de zaten o bağımsız program kapasitemizi daha da genişlettik. Kendi stüdyoları, kendi üretimhaneleri, kendi öğretim elemanı kapasitesi var. Dolayısıyla benim uzmanlığım olmamakla birlikte bu alanda ciddi yatırımlar yapanlardan biri olmanın keyfini yaşıyorum. Hem eğitim ve araştırma olarak, hem de araştırma altyapısı mahiyetinde. Üniversite de çok uzun bir süredir aslında çok destek veriyor. Çevrimiçi erişilebilirlik gibi. Bilindik, klasik eğitim ortamının üstüne çıkan, teknik vasıtaları kullanan MIT'nin yaptığı gibi, açık kaynak herkesin erişebildiği, sizin herkese erişebildiğiniz ortamlar üzerinden eğitim olanaklarının sürdürülmesi konusunda altyapısı daha zengin bir hale geliyor. Ama Türkiye'deki durumun ne olduğunu bilmiyorum. Ben sadece kendi fakültemde, öncelikle demesem de ciddi anlamda ağırlıklı mesele olarak görüldüğünü özellikle genç kadro tarafından sıklıkla kullanıldığını biliyorum. Hatta bazı derslerin çevrimiçi erişim üzerinden yapıldığı, açık kaynağa çevrildiği vs. rahatılıla söyleyebilirim" (Rzazade, 2018, s. 195). (Fot 33).

Özetle, birkaç köklü devlet üniversitesinde ve vakıf üniversitesinde teknolojik yeniliklerin mimarlık eğitim-öğretim programına ve mekanlarına dahil edildiği, onun dışında pek çok okulda akademisyenlerin bireysel çabalarıyla bu yeniliklerin kullanıldığı, özellikle ekonomik ve fiziki kısıtılıkların bu yeniliklerin kullanılmasını engellediği söylenebilir.

\section{- Ziyaret edilen üniversitelerdeki mimarlık eğitim-öğretim mekânlarının teknolojik yeniliklerle uyumu ve teknolojik yeniliklerin mekânlara etkisi}

Genel olarak, bir çok okulda mekânların boyut açısından yetersiz kaldığı ve teknolojinin kullanımına uygun hâle getirilmeye çalışıldığı, mekânları yeterli olan ve üretim laboratuvarları olan okullarda öğrenci sayısının çoğalması ile giderek mekânların yetersiz kalmaya başladığı, laboratuvarların stüdyolardan ayrı şekilde tasarlanmasının 
aynı anda tasarım ve üretim yapmayı engellediği belirtilmiştir. Bir kısım öğretim elemanı öğrencilere çalışma mekânlarının cazip gelmediğini ve müfredattaki yoğunluğun azaltılması gerektiğini, bir kısım öğretim elemanı teknolojik yeniliklerin mekânların niceliksel ve niteliksel özelliklerini hiç değiştirmediğini, bir kısım öğretim elemanı ise teknolojik yeniliklerin mekânların niceliksel ve niteliksel özelliklerini bir miktar değiştirdiğini, örnek olarak, sanal ortamlarda ders gören öğrenci için sınıf gerekmediğini, YÜ'de artık bütün öğrencilerin kendi bilgisayarları olduğu için bilgisayar laboratuvarlarının kaldırıldığını belirtmiştir (Rzazade, 2018, s. 101). Yapılan görüşmelerde öne çıkan bazı örnekler şöyledir:

\section{Görüşme 1: ITÜ Mimarlık Fakültesi Prof. Dr.}

..."Mekânlar uygun değil, onları adapte ediyoruz. Burası çok eski bir okul. Kışla olarak tasarlandığı için bazı mekânları teknolojinin imkânlarına göre adapte etmek durumundayız. Ama birebir teknolojik laboratuvar olarak veya FabLab olarak tasarlanmış veya üretilmiş bir mekânımız yok. Olan mekânları o fonksiyonlara adapte etmeye çalışıyoruz. Mesela, bir "RK" temin etmeyi düşünüyoruz. Onu nasıl adapte ederiz bu soru işareti. Ama bununla ilgili bir mekânımız hakikaten şu anda yok. Mekanlar niteliksel olarak tabii ki değişmek zorunda kalacaktır. Çünkü eğer öğrenciler sanal ders görürlerse, varsa bilgisayar laboratuvarında, yoksa kendi imkânlarıyla her yerde bu dersi alabilirler. İllaki sınıf olması gerekmiyor. Şu anda tam teknolojik bir sınıfımız yok, ama projeksiyonların dahil edilmesi, perdelerin yapılması, bunlar hemen hemen her sınıfımıza eklenen araçlar...Her ne kadar mükemmel çalışmasa da internet bağlantımız var. Okulun duvarları kalın olduğu için temel teknolojinin gerektirdiği bağlantıları yapabiliyoruz. O imkânları veriyoruz öğrencilere. Ama tabii tam olmuyor" (Rzazade, 2018, s. 128). (Fot 32).

\section{Görüşme 18: İDBÜ Mimarlık Fakültesi Doç.Dr.}

..."Mekânlar izin veriyor. Zaten stüdyolarımız oldukça donanımlı. Üretim aşaması için iki tane laboratuvarımız kullanıma girdi, üretim istenildiği zaman oralarda yapılabiliyor. Stüdyolarımızda öğrenciler her türlü bilgisayar ekipmanlarıı kullanabiliyorlar. Ayrıca bir tane otuz kişilik bilgisayar laboratuvarımız var. Seçmeli derslerimizi orada veriyoruz. Oradaki bilgisayarların kapasitesi çok uygun. Öğrenciler isterlerse kendi bilgisayarlarını getirebiliyorlar. Ama bizim oradaki donanımımız her türlü programı kullanmaya çok uygun. (Rzazade, 2018, s. 214).

Kısaca, vakıf üniversitelerinin mekansal ve teknolojik altyapı açısından devlet üniversitelerine göre daha iyi durumda olduğu görülse de, pek çok üniversitenin belli bir dönemde inşa edilmiş eğitim mekanlarına sahip olduğu ve bu mekanlara yapılan müdahalelerle mekanlara teknolojik altyapının adapte edilmeye çalışıldığı, teknolojik yeniliklerin mekanların niceliksel ve niteliksel özelliklerini değiştirmeye başladığı görülebilir. Bu noktada Türkiye'deki mimarlık eğitim mekânlarının teknolojik yeniliklere uyumlu olmadığı görülmüştür (3. Hipotez).

\section{- Ziyaret edilen üniversitelerdeki mimarlık eğitim-öğretiminde teknolojik yeniliklerin daha verimli olarak kullanılması için ihtiyaç duyulan mekanlar}

Görüşmelerde işbirlikçi eğitime imkân verecek daha esnek, geniş, ferah, iç içe, hangar tipi, kat yüksekliği fazla olan mekânların olması, BDT ve BDÜ derslerinin aynı anda, aynı mekânda paralel bir şekilde verilebilmesi için fablab'ların kurulması gerektiği; laboratuvarların stüdyolarla entegre şeklinde kullanılabilmesi, 24 saat açık kalması ve öğrencilerin orada sürekli üretim ve tasarım yapabilmelerinin sağlanması, termal ve görsel konfora uygun mekânların olması, laboratuvarların internet bağlantısının iyi çalışması, stüdyolarda priz ve oturma kısıtlılığının giderilmesi gerektiği ifade edilmiştir (Rzazade, 2018, s. 101-102 ). Yapılan görüşmelerden öne çıkan bazı örnekler aşağıda yer almaktadır:

\section{Görüşme 27: BUÜ Mimarlık Fakültesi Prof. Dr.}

..."Esnek mekânlar olmalı. Kapısı kapanan, kilitlenen, kontrollü değil de, aslında öğrencilere sorumluluk vererek ve uzaktan, belki de denetleyerek kullanmamız çok daha güzel olurdu...internet ortamının ve bir takım çıktı alınabilecek cihazların olması bize kafi gelebilir. Çünkü dizüstü bilgisayar demek adı üzerinde taşıyabilirsiniz...Bütün okulda bu esneklik sağlanırsa bence her yer stüdyo, her yer laboratuvar...Bence en güzel mimarlık okulu zaten kocaman bir uçak hangarı gibi bir yerdir. Kapısı olmayan, her tarafında stüdyo 
olan, esnek olarak değerlendirilen öyle bir mekânda çalışmak lâzım. İletişimin kopuk olduğu sınıflar ve öğretim üyelerinin ayrı ayrı odalarda olması konsantrasyon için belki gerekli olabiliyor, ama olabildiği kadar esnekleştirmek gerekiyor" (Rzazade, 2018, s. 263).

\section{Görüşme 17: TEDÜ Mimarlık Fakültesi Dr. Öğr. Üyesi}

..."Bence, ciddi stüdyolara ihtiyacımız var. Deneysel maket üretebilmek, öğrencilerin teknolojiyi deneyebilmeleri için...Ama bu stüdyolara mekânsal olarak yer ayrımı çok kolay değil. Artı oradaki malzeme desteği, orayı idare ettirecek kişinin desteği, maddi imkânsızlıklar sebebiyle de bunları yapmak çok kolay olmuyor. Genellikle sürdürülebilirliği çok olmuyor. Endüstri ürünleri tasarımı bölümünün olduğu yerlerde bu teknolojileri daha kolay kullanabiliyorlar. Çünkü onların mecburen üretim amaçlı stüdyoları olduğu için mimarlık bölümü de onu daha kolay kullanabiliyor. Üretim ve teknolojiyi bir arada kullanan bölümlerin varlığı teknoloji anlamındaki mekânların da sayısının artmasını sağlıyor, yatırımı daha da kolaylaştırıyor. Bir bölüm için bu tür yatırımlar daha kısıtlı yapılırken, benzer şekilde üretim yapan üç bölüm varsa daha kolay yatırım yapılıyor. Ama yeni üniversitelerde bu yatıımların biraz daha kısıtlı olduğunu söyleyebilirim" (Rzazade, 2018, s. 210).

Özetle, mimarlık eğitiminde teknolojik yeniliklerin verimli olarak kullanılabilmesi için mekan tasarımında öncelikle yeni kavramsal yaklaşımların üretilmesi gerekmektedir. İşlevsel açıdan, gerekli teknolojik altyapıyı barındırabilecek yeni boyutlar, biçimler, bağlantılar ve düzenlemeler kullanılabilir. Mevcut mekanların teknolojiyle adaptasyonunun istenilen sonucu vermeyeceği söylenebilir.

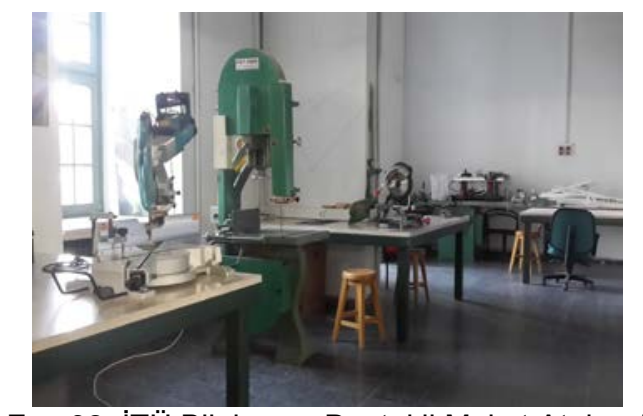

Fot. 32: ITÜ Bilgisayar Destekli Maket Atölyesi (Rzazade, 2018, s. 279-280)

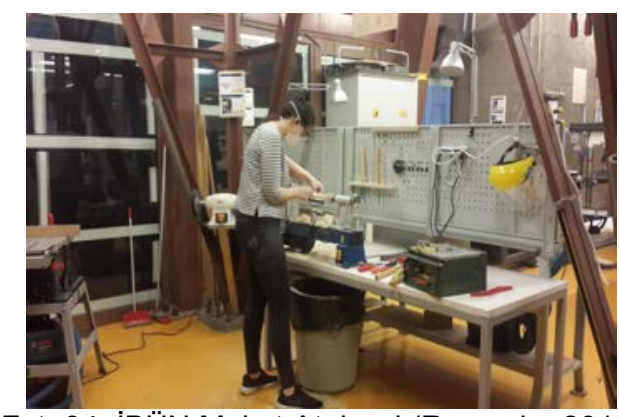

Fot. 34: İB̈N Maket Atölyesi (Rzazade, 2018, s.281-282)

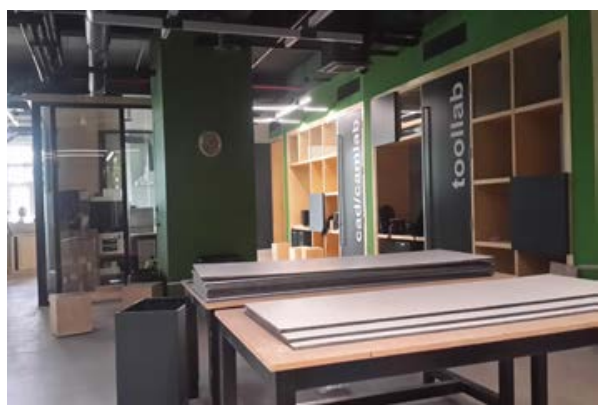

Fot.33: ODTÜ Üretim Laboratuvarı (Rzazade, 2018, S. 283-284)

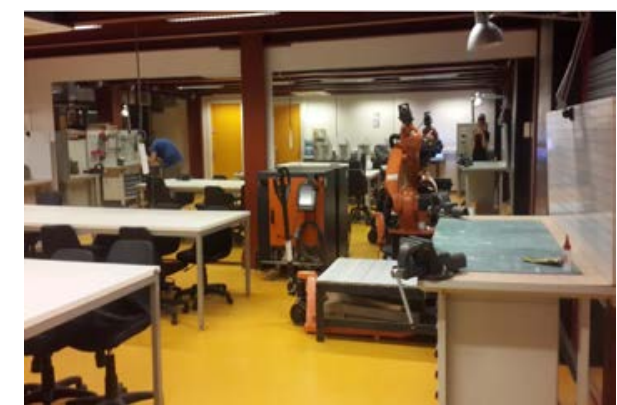

Fot. 35: İÜN Maket Atölyesi (Rzazade, 2018, s.281-282)

\section{DEĞERLENDİRME VE SONUÇ}

Sonuç olarak, çalışmada mimarlık eğitiminde kullanılan teknolojik yeniliklerin öğrencilere ve akademisyenlere pek çok avantaj sunduğu görülmektedir.

- eğitime esnek zaman- esnek mekân kavramını getirmek, yer bağımlıı̆ını ve bina gereksinimini azaltmak, 
- diğer ülkelerden farklı mimari yaklaşımları olan insanlarla veya farklı disiplinlerle ve kültürlerle birlikte çalışma imkanı sunmak, (Gül, Çağdaş, Çağlar, Gül, Sipahioğlu, 2013, s.12).

- tasarım fikirlerinin anında değiş-tokuş edilmesini kolaylaştırmak,

- geometrik/parametrik formların ve farklı malzemelerin çok çeşitli şekillerde kullanımına imkan vererek yeni tasarım dilleri geliştirmek, (Uzun, 2011, s. 845),

- tasarlanan ürünü farklı açılardan görebilmeyi ve deneyimleyebilmeyi, tasarımın çevresi ile ilişkisini ve uyumunu anlamayı sağlamak, mimari ürünü hızlı bir şekilde tasarlamak ve test etmek, (İbiş, 2009, s. vii ),

- yapım sistemini, yapı elemanlarını, malzemelerini, detaylarını projelere işleyerek gerçekçi bir şekilde sunmak ve bunları anında paylaşmak, (Yıldırım, Özen, İnan, 2008, s. 37- 45

- gerekirse 1:1 ölçekte prototip üretmek, (Çil, Çolakoğlu, Erdoğan, Özsel-Akipek, Pakdil, Yalınay-Çinici, Yazar, 2013, s. 4),

- tasarım sürecinde hızlı geri dönüş ve revizyonlara olanak vermek, böylece zaman ve çıktı açısından para tasarrufu sağlamak,

- gerçek dünyadaki üretim biçimleriyle ve aktörleriyle iletişim kurmalarını ve işbirliği yapmalarını sağlamak bunlardan sadece bazılarıdır (Celani, 2012, s. 469-482).

Kısaca, internet ortamında derslerin ve ödevlerin çevrimiçi paylaşılıp, değerlendirilip, tartışılmasının öğrencilere ve akademisyenlere zaman kazandıracağı, teknoloji sayesinde öğrencilerin ve akademisyenlerin daha fazla bilgi üretme ve beceri kazanma imkânlarına sahip olacağı, ekip çalışmalarının verimliliğinin artacağı, tasarım ve sunum tekniklerinin kolaylaşacağı, üretimle tasarımın aynı anda ve aynı mekânda yapılmasının yaratıcılığı tetikleyeceği, "öğrenen-öğrenen" eğitim sisteminin gelişeceği, bu durumun mimarların gelecekte uluslararası arenada daha serbest hareket etmesine imkan vereceği ve yapılan işlerin daha yüksek nitelikli olmasını sağlayacağı düşünülmektedir (Rzazade, 2018, s. 103-107). Diğer yandan, özellikle STS'larında iletişim, dijital bir ortam üzerinden gerçekleştiği için öğrencinin öğrenmesinde fiziksel etkileşime dayalı iletişim ve bilgi kaybı veya yanlış yorumlamalar olabileceği teknolojik yeniliklerin en önemli dezavantajları olarak görülmektedir (Yıldırım ve ark. 2014).

Alan çalışması kapsamında yapılan görüşmelerde Türkiye'de teknolojik yeniliklerin mimarlık eğitim mekânlarıyla yeteri kadar entegre edilmediği görülmüştür. Teknolojik yeniliklerin kullanımı konusunda sayılı devlet üniversitesi dışında maddi olanakları daha fazla olduğu için vakıf üniversitelerinin daha fazla öne çıktığı söylenebilir. Bu noktada 21. yüzyılın olmazsa olmazı olan teknolojik yeniliklerin her alanda olduğu gibi Türkiye'deki mimarlık eğitiminde ve mekânlarında kullanılabilmesi için uluslararsı örneklerin analizi üzerinden aşağıdaki öneriler geliştirilmiştir:

Teknolojik yeniliklerin kullanımı açısından:

- Mimarlık eğitiminin çağa ayak uydurması için gerekli teknik altyapı kurulmalıdır.

- Eğitimde geleneksel yöntemler kullanan üniversitelerin teknolojik yenilikler doğrultusunda dönüştürülmesi için bütçelerindeki ve akademik kadrolarındaki eksiklikler giderilmelidir.

- Öğrencilerle öğretim elemanları arasında nesil farkının azalması için gerekli önlemler alınmalı, öğretim elemanları teknolojik yeniliklerin kullanımına teşvik edilmeli, eğitim sürecinde teknolojik yeniliklerin kullanımı konusunda öğrencilere esnek davranılmalıdır.

Mimari tasarıma yön veren temel yaklaşımlar açısından: 
- geleceğe yönelik,

- esnek ve dinamik,

- işbirliğini ve disiplinlerarası çalışmayı sağlayabilen,

- sosyalliği güçlendiren,

- yenilikçi ve yaratıcı düşünmeyi destekleyen yaklaşımlar benimsenmelidir.

Teknolojiyi destekleyen mekânsal nitelikler açısından:

- teknolojik yeniliklere ayak uydurabilen esnek mekânlar,

- geniş ve yüksek katlı, hangar tipli mekânlar,

- fablab veya fablab+stüdyo gibi birlikte tasarım ve üretimi destekleyen yenilikçi mekânlar,

- çok amaçlı, bireysel veya grup olarak serbest kullanıma izin veren total mekânlar,

- 24 saat çalışmaya imkan verecek şekilde donatılmış mekânlar tasarlanmalıdır (Rzazade, 2018,s. 103-107).

Çalışmasının başında da ifade edildiği gibi teknolojik yenilikler mekânsal gereksinimleri değiştirir ve mekânsal gereksinimlerin yeterliliği eğitimin kalitesini etkiler. Bu noktada yapılan çalışma yurtdışındaki teknoloji odaklı mimarlık okulları ile Türkiye'deki mimarlık okulları arasında teknolojik yeniliklerin kullanımı, buna bağlı olarak ortaya çıkan tasarım yaklaşımları ve mekânsal gereksinimler konusunda dikkate değer sonuçlar ortaya koymuştur. Çalışmanın Türkiye'deki eğitim ve mimarlık disiplinleri arasındaki ilişkiyi güçlendireceği, mimarlık eğitiminin geliştirilmesine ve dünyadaki öncü okullarla rekabet etme gücüne katkı koyacağı düşünülmektedir.

\section{KAYNAKLAR}

Achten, Henri; Koszewski, Krzysztof; Martens, Bob, 'What Happened after the 'Hype' on Virtual Design Studios? Some Considerations for a Roundtable Discussion" In: University of Ljubljana (ed.), Proceedings of the 29th International eCAADe Conference, Ljubljana, 2011, s.24.

Brell-Çokcan, Sigrid; Braumann, Johannes, "Industrial Robots For Design Education: Robots As Open Interfaces Beyond Fabrication" CAAD Futures, 2013, s. 109-117.

Çağıltay, Kürşat; Yıldırım, Soner; Arslan, İsmahan; Gök, Ali; Gürel, Gizem; Karakuş, Türkan; Saltan, Fatih; Uzun, Erman; Ülgen, Erden; Yıldız, İsmail, "Öğretim Teknolojilerinin Üniversitede Kullanımına Yönelik Alışkanlıklar ve Beklentiler: Betimleyici Bir Çalışma" Akademik Bilişim'07 - IX. Akademik Bilişim Konferansı Bildirileri, Dumlupınar Üniversitesi, Kütahya, 2007, s. 214-215.

Duru, Sibel, Sanal Mimari Tasarım Stüdyosunda Pedagojik Yaklaşımlar, İstanbul Teknik Üniversitesi, Fen Bilimleri Enstitüsü, Yüksek Lisans Tezi, İstanbul 2006, s. 37.

Gomez Galan, Jose "Educational Architecture and Emerging Technologies: Innovative Classroom Models", University of Extremadura (Spain) \& Metropolitan UniversityAGMUS (Puerto Rico -USA), 2017, s. 11-12, 15.

Garrison, Randy; Kanuka, Heather, "Blended Learning: Uncovering its Transformative Potential in Higher Education", Internet and Higher Education, Kanada 2004, s. 95-105. 
İbiş, Ali, Mimari Eğitimde Simülasyon Kullanımı, Yıldız Teknik Üniversitesi, Fen Bilimleri Enstitüsü, Yüksek Lisans Tezi, İstanbul 2009.

Karataş Acer, Ebru; Güçlü, Nezahat, "Türkiye'de Yükseköğretimin Genişlenmesi: Gerekçeler Ve Ortaya Çıkan Sorunlar” Yükseköğretim Dergisi, 2017, s. 28-29, 32-33.

Kolarevic, Branko, "Architecture in the Digital Age: Design and Manufacture" , Spon Press, London 2003, s. 314.

Köymen, Erdem, Mimari Ön Tasarım Sürecinde Eskizleri Gerçek Zamanlı 3B Modelleyen, Arttırımış Gerçeklik Destekli Bir Yazılım Denemesi: "Sketchar", Yıldız Teknik Üniversitesi, Fen Bilimleri Enstitüsü, Doktora Tezi, İstanbul 2014.

Masdeu, Marta; Fuses, Josep, "Reconceptualizing, The Design Studio in Architectural Education: Distance Learning And Blended Learning As Transformation Factors" Archnet-IJAR: International Journal of Architectural Research, İspanya 2017, ss.6-23.

Mutluer, Kamil M., "Türkiye'de Yükseköğretimin Başlıca Sorunları ve Sorunlara Çözüm Önerileri” T.C. Maliye Bakanlığı Strateji Geliştirme Başkanlığı, Ankara, 2008.

Özsel Akipek; İnceoğlu, Necati, "Bilgisayar Destekli Tasarım ve Üretim Teknolojilerinin Mimarlıktaki Kullanımlari”, Megaron Dergisi , 2007, s.247.

Özgenel, Lale, "6 Mimar ve Akademisyenin Mimarlık Eğitim Modeli Üzerine Düşünceleri." https://yapidergisi.com/6-mimar-ve-akademisyenin-mimarlik-egitimmodeli-uzerine-dusunceleri/ , 2020. (Son Erişim Tarihi: 06.12.2020, saat: 16.00).

PAB, "Nitelikli Eğitim- Öğrenim Için Nitelikli Mekanlar", 2016 http://www.ogrenimmekanlari.com/?view=classic, (Son Erişim Tarihi: 06.12.2020, saat: 17.00).

Rzazade, Dilara, "Teknolojik Yeniliklerin Mimarlık Eğitimindeki Mekânsal Gereksinimlere Etkisi Üzerine Bir Araştırma", Bursa Uludağ Üniversitesi, Yüksek Lisans Tezi, Bursa, 2018, s. 3; 4; 13; 95; 96; 96-102; 101; 103-107; 128;146; 176-177; 187; $195 ; 210 ; 214 ; 224 ; 228 ; 234 ; 253-254 ; 263 ; 279-80 ; 281-282 ; 283-284$.

South, Joseph, Reimagining the Role of Technology in Higher Education, Office of Educational Technology, US 2017, p.84.

Sood, Raghav, Pro Android Augmented Reality, Apress, New York, 2012.

Schubert, Gerhard; Strobel, Benjamin; Petzold, Frank, "Tangible Mixed Reality, In Proceedings of the $21^{\text {st }}$ International Conference on Computer-Aided Architectural Design Research in Asia" 2016, Melbourne, Australia.

Şenses, Fikret, "Uluslararası Gelişmeler Işığında Türkiye Yükseköğretim Sistemi: Temel Eğilimler, Sorunlar, Çelişkiler ve Öneriler", Economic Research Center, 2007, s. 3.

TMMOB Mimarlar Odası, "Mimarlık ve Eğitim Kurultayı IX, Türkiye Mimarlık ve Eğitim Politikaları", 2018, s. 119, 138-140.

TMMOB Mimarlar Odası, “Türkiye Mimarlık Eğitimi Politikası”, 2020, s. 4,5,8. 
Türk Eğitim-Sen, “Türkiye'de Yükseköğretimin Sorunları, Beklentiler ve Çözüm Arayışları Çalıştayı” , Türk Eğitim-Sen Genel Merkezi, 2012.

Uzun, Türkan, "Mimarlık Eğitiminde Kullanılan Dijital Tasarım Programlarının Bellek ve Tasarım Sürecine Katkıları", Akademik Bilişim'11 - XIII. Akademik Bilişim Konferansı Bildirileri, 2011, s. 845.

Yıldırım, Tayfun; Özen, Arzu; İnan, Nurgül, "Uzaktan Mimari Tasarım Eğitiminde İnternet Teknolojilerinin Kullanımı" Bilişim Teknolojileri Dergisi, 2008, s. 37-45.

Yıldırım, Tayfun; Özen Yavuz, Arzu; İnan, Nurgül, "Mimari Tasarım Eğitiminde Bilişim Teknolojilerinin Kullanımı ve Etkileri”, Gazi Üniversitesi, 2014.

Yiğit, G. Yasemin; Zayim, Neşe; Yıldırım, Soner, "Yükseköğretimde Öğretim ve idari Amaçlı Teknoloji Kullanımı: Bir Durum Saptaması",Eğitim ve Bilim Dergisi, 2002, s. 4950.

Wall, Tony D.; Clegg, Chris W.; Kemps, Nigel J.; The Human Side Of Advanced Manufacturing Technology, John Wiley and Sons Ltd, West Sussex , 1987, p. 464.

URL - 1, Top Ranked Architecture Schools Focus Areas, https://www.dirankings.com/twelve-focus-areas-architecture/ (Son erişim tarihi: 01.12.2020).

URL - 2, University Subject Rankings 2020, https://www.topuniversities.com/universityrankings/university-subject-rankings/2020/architecture (Son erişim tarihi: 01.12.2020).

URL - 3, Frank Gehry Teaches Design and Architecture, https://www.masterclass.com/classes/frank-gehry-teaches-design-and-architecture (Son erişim tarihi: 05.09.2017).

URL - 4, Building Information Modeling / Integrated Project Delivery http://www.wsarchitects.com/expertise-bim_ipd.html (Son erişim tarihi: 07.12.2020).

URL - 5, "Online presentation authoring tool Cl3ver adds offline publishing to extend the availability of content", http://gfxspeak.com/2014/04/23/cl3ver-offline-option/ (Son erişim tarihi: 10.07.2017).

URL - 6, Digital Exibition, Nottingham, 2018, http://feillustration.co.uk/2011/03/digitalexhibition/ (Son erişim tarihi: 13.05.2018).

URL - 7, University of Liverpool Virtual Tour, UK. https://www.liverpool.ac.uk/architecture/about-us/virtual-tour/ (Son erişim tarihi: 09.06.2017).

URL $\quad-\quad$ 8, CAP Atrium Project, https://capvrenvironment.wordpress.com/2013/01/17/cap-atrium/ (Son erişim tarihi: 13.05.2018).

URL - 9, Georgia Institute of Technology, Hinman Building, Atlanta. https://www.news.gatech.edu/features/yellow-jackets-swarm-capitol (Son erişim tarihi: 10.07.2017). 
URL - 10, University of Waterloo Fabrication Labs, Canada. https://uwaterloo.ca/architecture/resources-services/fabrication-labs (Son erişim tarihi: 20.05.2017).

URL - 11, Stevens, Tham \& Videgård Completes Corten-Clad School Of Architecture In Stockholm, https://www.designboom.com/architecture/tham-videgard-arkitekterschool-of-architecture-kth-stockholm (Son erişim tarihi: 10.07.2017).

URL - 12, UNStudio Completes First Buildings for New Singapore University Campus, New York, https://www.dezeen.com/2015/06/03/unstudio-singapore-university-campusbuildings-dp-architects-sutd/ (Son erişim tarihi: 10.07.2017).

URL-13, TU Delft Architecture Faculty Model Studio, https://books.bk.tudelft.nl/index.php/press (Son erişim tarihi: 13.05.2018).

URL - 14, MIT School of Architecture and Planning, https://www.Iwaarchitects.com/project/mit-school-of-architecture-and-planning/ (Son erişim tarihi: 13.05.2018).

URL - 15, ETH Zurich Arc.Tec.Lab. Zurich, https://projets.batidoc.ch/archteclab-ethhonggerberg (Son erişim tarihi: 13.05.2018).

URL - 16, "Architects Using Robots to Build Beautiful Structures", https://spectrum.ieee.org/automaton/robotics/industrial-robots/robots-in-architecture (Son erişim tarihi: 13.05.2018). 